Riget og herligheden som det klart mest interessante af hans værker og derfor ikke er så interesseret i Agamben som sprog- eller eksistensfilosof - hvilket Sprogets sakramente lægger sig tæt op af (og som også var den filosofi Agamben bedrev før han hengav sig til Homo sacer projektet). På den måde er Sprogets sakeramente et underligt lille værk, som nok ikke vil finde interesse hos andre end de hardcore Agamben-fans, og som man derfor, til trods for det bestemt beundringsværdige heri, kan undre sig lidt over er blevet oversat til dansk. Det samme kunne man sige var tilfældet for Nogenhed, men her er trods alt en lidt bredere appel, eftersom også bare almindelige Agamben-interesserede (og ikke kun de hardcore-fans) vil kunne finde den interessant, netop fordi den leverer nogle sjove analyser og undersøgelser og på den måde giver fine perspektiver på Agambens arbejde for dem der kender lidt til ham. Men om det giver mening for så mange andre må så forblive et åbent spørgmål. Men indtil videre, og uanset, kan vi jo glæde os over den øgede Agamben-interesse i vores lille land.

Mathias Hein Jessen

\section{Regeringens genea-} logi

Giorgio Agamben: The Kingdom and the Glory, Stanford University Press, 2011,328 sider, 24,95 USD.

Fire år efter sin udgivelse er den italienske idéhistorikers Il regno e la gloria langt om længe udkommet på engelsk. Udgivelsen indgår i Agambens Homo Sacer-projekt, der i skrivende stund tæller syv udgivelser. Fra de overvejende filosofiske overvejelser i de tidlige Homo Sacer-udgivelser har Agamben i stigende grad bevæget sig imod en mere idéhistorisk kritik - à la den franske idéhistoriker Michel Foucault - og denne finder indtil videre sit absolutte højdepunkt $\mathrm{i}$ The kingdom and the glory.

Ifølge Agamben er den vestlige politiske tænkning gået galt i byen. Lidt kækt kan man sige, at Agamben i The kingdom and the glory fordobler Tertullians kritik af forskningen i politik helt tilbage fra de første århundreder: "Mens latinere har det med at udbryde 'monarki', nægter selv grækere at forstå økonomien" (Tertullian citeret i Agamben 2011a: 14). Det politiske spørgs- 
mål handler ikke dybest set om styreformen, det handler om økonomien. Mens vi i dag har det meget med at tale om demokrati, nægter man at forstå den moderne regeringsform: Økonomien. I The kingdom and the glory er det derfor økonomi-begrebet, der står for tur i Homo Sacer-projektets revision af den vestlige politiske tænkning. Dette sker på baggrund af det faktum, at før økonomien fra midten af 1700-tallet begyndte at udparcellere sig som en selvstændig organisations-, fordelings- og vidensform, var økonomien forstået som regering og forvaltning: Guds regering af verden og de kristnes forvaltning af åbenbaringen. Økonomien er altså dybest set en regeringsstrategi, mens regeringen samtidig altid må benytte sig af en økonomi, dvs. en strategi for hvor og hvordan, der skal regeres, for at der regeres så effektivt som muligt.

I bogens Appendiks diskuterer Agamben, hvordan økonomien genintroduceres $i$ vestlig politisk tænkning som 'politisk økonomi' - først og fremmest hos tænkere som J.J. Rousseau og Adam Smith - men Agambens analyse har sit hovedfokus i den tidlige kristne tænkning fra om- kring år 30-350. Før de kristne betegner økonomi en fordeling, strategi eller organisation. Men modsat eksempelvis politikken, der har et mål, betegner økonomien ene og alene selve optimeringen. Som det eksempelvis hedder i den ikke-kristne romerske kejser Marcus Aurelius' (121-180) Meditationer betegner økonomi ifølge Agamben "en praksis og ikke-epistemisk viden, som kun kan benyttes i sammenhæng med de mål, der forfølges" (Agamben 2011a: 19).

Begrebet ændrer imidlertid karakter med den kristne reception. Den kristne indoptagelse og omformning af økonomibegrebet falder for Agamben i to etaper. I første omgang drejer det sig for de kristne om at forklare "mysteriets økonomi", mens det sidenhen vil dreje sig om at forklare "økonomiens mysterie" (Agamben 2011a: 26). Agamben undersøger derfor i bogens andet kapitel udviklingen af økonomi-begrebet, og den måde man tænker økonomien på, i de første århundreders kristne tænkning. Agamben fremlæser et væld af nuancer og interessante elementer, men blandt de vigtigste er adskillelsen mellem Guds væren og Guds gøren. 
Denne forestilling læser Agamben især frem af diskussioner af treenigheden: Hvordan kan Gud på paradoksal vis på én gang være én og tre? Men det er slet ikke noget paradoks, og der er intet problem $i$ at opretholde både treenigheden og den almægtige Gud, siger den kristne tænker Hippolytus (170-235): "Når alt kommer til alt, vil alle så ikke sige, at der er en enkelt Gud? - men vi skal ikke glemme økonomien" (Hippolytus citeret i Agamben 2011a: 37). Hermed introduceres et skarpt skel mellem Guds væren og hans plan / strategi (oikonomia). At Gud blev til menneske, var ganske enkelt en del af hans oikonomia, og han behøver ikke intervenere i verden eller reparere på sit værk, for det hele har været planlagt på forhånd. Som Agamben pointerer, er det ikke længere som hos Paulus, mysteriet (frelsen) der kræver en plan, men selve Guds plan der er mysteriet: Hvordan er det muligt for Gud at gøre dette? Hvordan var det muligt at koncipere og udføre denne plan?

Denne forestilling går $\mathrm{i}$ forskellige former igen blandt en række af de tidlige kristne tænkere. Hos Tertullian (ca. 160-225) tager tankefiguren form af en enkelt guddommelig væren, som benytter sig af forskellige administrative og praktiske økonomier. Hos Clement (ca. 150-215) er der et utal af økonomier: en økonomi for huset, en økonomi for stjernerne, og endda en økonomi for mælken, som får den til at flyde fra moderens bryst og ernære barnet - men vigtigst er "økonomien for frelseren" (Agamben 2011a: 46-47). Fælles for disse tænkere er, at Gud fra starten har skabt en administration, der kan forvalte frelsen. Det væsentlige her er for Agamben, at der indføres et væsentligt skel mellem den suveræne skaber (Gud) og forvaltningen af hans projekt (englene, apostlene, kirken, osv.). Det er altså ikke længere den almægtige selv, der handler. I stedet er der et fællesskab eller et apparat, som forvalter den almægtiges vilje. Eller som Agamben formulerer det i én blandt et utal af parafraser over denne pointe:

Den guddommelige væren er ikke splittet, siden den tredeling, som [kirke]fædrene taler om, befinder sig på niveauet for oikonomia, ikke ontologi. Det brud, som måtte undgås for enhver pris på ontologiens niveau, genopstår til gengæld som en splittelse mellem Gud og hans handlen, mellem ontologi og praksis 
(Agamben 2011a: 53).

Eller som Agamben spidsformulerer pointen med et ikonisk citat "Le roi règne, mais il ne gouverne pas" - konger hersker, men regerer ikke (Agamben 2011a: 9). Agamben henviser ikke til ophavsmanden, men det er første gang formuleret af den infamøse franske politike Adolphe Thiers i 1830, som var en egalitær anti-royalist, der senere i sit liv som regeringsleder var med til at knuse Pariserkommunen. Denne formulering står $\mathrm{i}$ øvrigt også den franske idéhistoriker Michel Foucault nært i de år, hvor han udvikler forestilling om en guvernementalitet (en slags selvlegitimerende regeringsfornuft), og som Agamben trækker heftigt på $\mathrm{i}$ The kingdom and the glory (se min artikel "...ikke Gud, men hans engle..." tidligere i dette nummer for en uddybning af dette). Men i modsætning til Foucault, der ser citatet som udtryk for en politisk-forestillingsmæssig nyudvikling, læser Agamben citatet som udtryk for en fundamental forestilling, som kan spores tilbage til den tidlige kristne tænkning om Guds regering af verden og det kristne samfunds forvaltning af åbenbaringen - altså $\mathrm{i}$ den kristne menighed og kirken. Vi mang- ler med Agambens ord stadig at forstå "implikationerne for den vestlige politiks historie af det faktum, at det messianske samfund repræsenteres begrebsligt som en oikonomia - ikke som en politik" (Agamben 2011a: 25).

Hermed er vi nået frem til Agambens grundtema; nemlig, at der er en fundamental splittelse mellem væren og handlen på det politiske og religiøse plan. Dette tema varierer Agamben gennem resten af bogen igen og igen. I forhold til bønnen og lovsangens betydning. I forhold til middelalderens teologi, hvor især Agambens læsninger af middelalderens lære om engle som forløber for det moderne bureaukrati og hierarki (i en figur hvor englen / embedsmanden på en gang administrerer magten og priser suverænens tomme plads) er forbilledlig. Men også i forhold til EU, der fungerer som ren regering uden en egentlig suverænitet.

Agambens bog er et eminent stykke idéhistorisk arbejde over bærende politiske forestillinger som økonomi, regering, folkeligt bifald og magtens glorværdighed. Ikke mindst den måde, hvorpå han undersøger herkomsten af dominerende politiske forestillinger $i$ et ikke oplagt kildemateriale, og på den måde implicit 
formår at fremlæse overraskende konsekvenser af den moderne politiske tænken og ageren. Derudover fungerer bogen som et stærkt bidrag til Foucaults undersøgelser af guvernementalitet, der både raffinerer begrebet $\mathrm{og}$ anviser en række nye idéhistoriske felter, hvor begrebet kan fungere produktivt. Agambens bog taber lidt pusten mod slutningen og især analyserne af pragt og glorværdighed er lidt længere i spyttet og lidt mindre nuancerede end analyserne af økonomi, men det forhindrer ikke bogen i at være en begivenhed indenfor Foucault-inspireret idéhistorie og politisk filosofi, som enhver med sådanne interesser skylder sig selv at læse.

\section{Nicolai von Eggers}

\section{Klarhed over det Løg- strupske landskab}

David Bugge: Hinandens Verden: Ledsager til K.E. Logstrup: Den etiske Fordring, Klim, 2011, 359 sider, 299 kr.

David Bugge: Kompendium til Den etiske Fordring, Klim, 2011, 95 sider, $129 k r$.
"Klarhed er det sidste tilflugtssted for dem, der intet har at sige", sagde Friedrich Waismann, en påstand man med et glimt i øjet kunne forestille sig at K.E. Løgstrup ville tilslutte sig. Ikke at Løgstrup ikke havde noget at sige. Tværtimod. Men for enhver, der har stiftet bekendstskab med Den etiske Fordring (herfra refereret til som DEF) må det stå klart, at K.E. Løgstrup med sit hovedværk ikke ligefrem har begået en læse-let bog. Dette skyldes ikke blot Løgstrups forkærlighed for at strække det danske sprog til dets yderste. En mindst ligeså vigtig faktor er de mange lag og facetter, der gemmer sig i teksten og dens ærinde, samt de mange forskelligartede tænkere og tankestrømme Løgstrup i dette værk giver sig i lag med. Læsningen af DEF kan altså brydes i mindst ligeså mange prismer som den fordring hvorom Løgstrup taler, og det kan gøre det svært for selv den engagerede læser.

Udfordringen skulle således være til at få øje på for den der, som David Bugge, ønsker at en skrive en ledsager til bogen, der på én gang skal henvende sig til forskere, studerende og den alment interesserede. Og opga- 